\title{
Profile of Maternally Derived Antibody in Broiler Chicks and In-Ovo Vaccination of Chick Embryo against Newcastle Disease
}

\author{
George 0. Okwor, Abduldahiru El-Yuguda, Saka S. Baba* \\ Animal Virus Research Laboratory, Department of Veterinary Microbiology and Parasitology, Faculty of \\ Veterinary Medicine, University of Maiduguri, Maiduguri, Nigeria \\ Email: ${ }^{*}$ aramidebaba@gmail.com
}

Received 13 March 2014; revised 14 April 2014; accepted 21 April 2014

Copyright (C) 2014 by authors and Scientific Research Publishing Inc.

This work is licensed under the Creative Commons Attribution International License (CC BY).

http://creativecommons.org/licenses/by/4.0/

(c) (i) Open Access

\begin{abstract}
In this study, we determined the suitability of lentogenic LaSota and naturally occurring avirulent $I_{2}$ vaccine strains of Newcastle disease (ND) virus for efficacious in-ovo vaccination of broiler chickens. A total of 114 embyonated eggs divided into five groups (A, B, C, D and E) consisting of 25 eggs in each of groups $A$ and $B, 20$ eggs in each of groups $C$ and $D$ and 24 eggs in group $E$ were used in the study. Eighteen-day-old embryonated eggs in group A were vaccinated in-ovo with ND-I $\mathrm{I}_{2}$ vaccine while the same age of embryos in group $B$ were vaccinated with ND-LaSota. Thirteen-dayold embryonated eggs in groups $C$ and $D$ were vaccinated with $N D-I_{2}$ and ND-LaSota respectively. Group E served as unvaccinated control. There was significant difference $(p<0.05)$ in percentage hatchability between the vaccinated and control groups. Highest hatchability $(64 \%)$ was recorded in group $A$ when compared to other vaccinated groups (B [36\%], C [10\%] and D [5\%]). The difference in embryonic mortality between groups was also statistically significant. The lowest mortality rate $(36 \%)$ was recorded in group A when compared with group D $(95 \%)$, group C $(90 \%)$ and group B (64\%). In spite of the pre-existing maternal antibody, the in-ovo vaccinated embryos seroconverted to protective antibody titres (GMT of $5.7 \pm 0.00-7.30 \pm 2.08$ ) when compared with the control group $E$ which had non protective antibody titre GMT of $3.00 \pm 2.75$ and decayed faster in chicks after hatching. There was significant rise in antibody titre (anamnestic response) in all experimental chicks following booster vaccination on day 37 post hatching. It is concluded that the ND vaccines (LaSota and $I_{2}$ ) used for the in-ovo vaccination were pathogenic for chick embryos, however, $\mathrm{ND}-\mathrm{I}_{2}$ vaccine was better tolerated when administered to 18-day-old chick embryo.
\end{abstract}

\section{Keywords}

In-Ovo Vaccination, ND-LaSota, ND-I ${ }_{2}$, Maternal Antibody, Broiler Chicks

\footnotetext{
"Corresponding author.
}

How to cite this paper: Okwor, G.O., et al. (2014) Profile of Maternally Derived Antibody in Broiler Chicks and In-Ovo Vaccination of Chick Embryo against Newcastle Disease. World Journal of Vaccines, 4, 72-80. 


\section{Introduction}

Newcastle disease (ND) is a viral disease that affects a wide range of poultry species irrespective of age [1] [2]. However, species difference in immune response to ND virus infection has been reported [3]. ND is a major setback in poultry production all over the World. In Africa and Asia, it is a major constraint to the development of both industrial and village poultry production [4]. ND has been reported to be endemic in Nigeria and there is seasonality in its prevalence [5] [6]. The disease is caused by ND virus which is a member of the genus Avulavirus of the family Paramyxoviridae (Paramyxovirus1) [7]. ND virus can be classified into five pathotypes based on clinical signs induced in infected chicken [2] [8] [9]. Transmission is by ingestion of infected feed or inhalation of infected fomites and windborne spread of ND has been reported [10]. Breeders vaccinated against ND or infected with field strain of the virus are able to transfer antibodies to the embryo through the yolk [11]-[13]. Chicks from immunized parents possess high level of maternal antibody (MA) which protects the chicks against virulent and vaccine viruses [11] [14] [15]. Some earlier reports showed that MA is protective [14] and neutralizes vaccine virus if the chicks are vaccinated in the presence of high level of MA [12] [13] [16]. In spite of the significant advances in poultry vaccine production which include considerable improvement in their efficacy, outbreaks of infectious diseases continue to occur among vaccinated and unvaccinated poultry flocks [17]-[19]. Recently an in-ovo vaccination technique has been developed that has several advantages over the conventional methods including, neonatal resistance, administration of uniform dose of virus and better protection, administration of vaccine in eggs en masse, reduction in labour cost and limited farmers involvement [20] [21]. As the name implies, in-ovo vaccine is administered in embryonated eggs with help of an in-egg vaccine delivery system, and soon after hatching birds are protected against the disease for which it is administered. In-ovo vaccination has proved to be effective against Marek's disease (MD), and infectious bursal disease (IBD) of poultry [22] [23]. However, several live vaccines cannot be administered in-ovo, mainly because vaccine viruses cause considerable embryo mortality [24] [25], reduced hatchability [22], or development of clinical disease after hatch. Selection of highly attenuated virus strain, virus modification, and inoculum dose that exert least harmful effects on embryos or neonatal chicks are critical in the development of a live vaccine for in-ovo application [26]. This study was designed to determine the suitability of lentogenic LaSota and naturally occurring avirulent $\mathrm{I}_{2}$ vaccine strains of ND virus for efficacious in-ovo vaccination in broiler chickens by prolonging the duration of antibody decay and overcoming interference of MA with vaccination.

\section{Materials and Methods}

\subsection{Experimental Design}

A total of 200 embryonated chicken eggs from ND vaccinated hens were obtained from a commercial hatchery in Nigeria, out of which 124 eggs were found viable and used for this study. Prior to the experiments, ten eggs were selected at random and used to determine the baseline antibody titre (MA) using haemagglutination (HA) and haemagglutination Inhibition (HI) test as described previously by [27]. The remaining 114 eggs were divided into 5 groups; A, B, C, D, and E consisting of 25 eggs in each of groups A and B, 20 eggs each in groups $\mathrm{C}$ and $\mathrm{D}$ and 24 eggs in group E. Eggs in group A were vaccinated with $\mathrm{ND}-\mathrm{I}_{2}$ vaccine on the $18^{\text {th }}$ day of egg incubation. Group B was vaccinated with ND-LaSota on the same day of incubation while groups C and D were vaccinated with $\mathrm{I}_{2}$ and LaSota respectively on the $13^{\text {th }}$ day of egg incubation. Group E served as unvaccinated control. After hatching blood samples were collected from the chicks on days 7, 14, 21, 28, 35, 42 and 49 post hatching $(\mathrm{PH})$ to determine the antibody profile among vaccinated and control chicks. On day $37 \mathrm{PH}$, all the groups were booster vaccinated with LaSota and $\mathrm{I}_{2}$ vaccines respectively. Group $\mathrm{F}$ consisted of 25 day-old chicks of the same age as the experimental chicks and were vaccinated intraocularly. The antibody profiles of birds in group $\mathrm{F}$ were monitored alongside those of experimental chicks (hatched from in-ovo vaccinated embryos). The weight and other physical parameters were determined for all experimental birds throughout the period of the experiment. Mortality pattern was also monitored and recorded.

\subsection{Extraction of Egg Yolk Maternal Antibody}

Egg yolk maternally derived antibody was extracted from each of the 10 eggs selected at random from the 124 experimental embryonated chicken eggs to determine the baseline antibody titre (maternal antibody titre). The method previously described by [28] for extraction of antibody from egg yolk was used in this study. Briefly, 
eggs were aseptically broken into a clean Petri dish. One millilitre of the yolk was collected using a clean syringe and transferred into a clean test tube. One millilitre of PBS (pH 7.4) was added to $1 \mathrm{ml}$ of egg yolk and mixed thoroughly. Two millilitres of chloroform was then added and the tube shook vigorously, the mixture was centrifuged at $1500 \mathrm{rpm}$ for 30 minutes and then incubated at $4^{\circ} \mathrm{C}$ for 1 hour. The clear fluid between the lipid droplets on the top and the yolk solid at the bottom of the test tube was harvested and used for haemagglutination inhibition (HI) test to determine the presence of maternal antibody in the egg yolk.

\subsection{Egg Incubation and Hatching}

All the experimental embryonated eggs were incubated at $37^{\circ} \mathrm{C}$ using manually controlled incubator. The eggs were incubated for 24 days. Eggs were disinfected before setting into the incubator, were aseptically turned twice daily, and candled weekly for viability beginning from day 7 post incubation.

\subsection{Newcastle Disease Vaccines and Administration}

ND vaccines (LaSota and $\mathrm{I}_{2}$ ) batch numbers 20/2009 and 24/2009 respectively were obtained from National Veterinary Research Institute, Vom, Nigeria (http://nvri.gov.ng). The ND LaSota vaccine is live attenuated and used for active immunization of chicks at the age of 3weeks against the disease while ND- $\mathrm{I}_{2}$ vaccine is avirulent and thermostable used for active immunization of local village chickens at any age against the disease. The vaccines were inoculated through the chorioallantoic sac route using $1 \mathrm{ml}$ needle and syringe. Two hundred dose vial of LaSota vaccine was reconstituted in $20 \mathrm{ml}$ of normal saline and inoculated in $0.1 \mathrm{ml}$ volume into each of the corresponding experimental eggs using $1 \mathrm{ml}$ needle. While a 50 dose vial of ND- $\mathrm{I}_{2}$ vaccine was reconstituted in $5 \mathrm{ml}$ of normal saline and inoculated in $0.1 \mathrm{ml}$ volume into each of the eggs in the corresponding groups. The inoculation was made through a hole aseptically drilled using a manual egg driller on the large end of the egg through the air space into the chorioallantoic sac. The inoculation site was then sealed using paraffin wax. A 0.1 $\mathrm{ml}$ volume of normal saline was administered to each egg in the control group $\mathrm{E}$ as described above.

\subsection{Collection of Blood Samples from Chicks after Hatching}

Due to the small size of the chicks, blood samples were collected on filter paper on days $7,14,21,28,35,42$ and 49 post-hatching through the wing vein. The weights of the birds were taken weekly before blood sample were collected. At older age of chicks, blood for serum was also obtained along side with the filter paper blood samples.

\subsection{Elution of Filter Paper}

The elution of filter papers carrying blood was carried out as previously described [6]. Briefly, the filter papers were air dried at room temperature and stored at $4^{\circ} \mathrm{C}$ in polypropylene bags until needed. The papers were eluted by cutting punches (discs) of $6.1 \mathrm{~mm}$ diameters from blood stained area on filter paper with a hand punch and placed in flat bottom microtitre plate. Sterile normal saline $(0.1 \mathrm{ml})$ was placed in each well containing two discs of filter paper punch. The eluted extract was analysed by haemagglutination inhibition (HI) test to determine the presence of antibody to ND virus.

\subsection{Virus Antigens Used in HI Test}

ND LaSota and $\mathrm{I}_{2}$ vaccine batch numbers 20/2009 and 24/2009 respectively obtained from NVRI, Vom, Plateau State, Nigeria were used as antigen for the HA/HI test.

\subsection{Haemagglutination Inhibition Test}

The modified microhaemagglutination-inhibition test previously described [27] was performed on the egg yolk extracts, filter paper eluents and sera (where available) using $0.9 \%$ chicken erythrocyte suspension as indicator. The extracts, eluents and sera were tested in a two-fold serial dilutions with PBS against 8 haemagglutination (HA) units of ND antigen (4 - 8 HA units usually employed in the HI test). Extracts and eluents with titres less than 1:4 were considered negative in order to ensure the specificity of the HI test. The highest dilution of the positive egg yolk extract and filter paper eluate showing a 50\% inhibition of haemagglutination was considered 
as the endpoint HI titre.

\subsection{Booster Vaccination}

On day 37 post hatching, all the hatched chicks (from vaccinated eggs) were booster vaccinated by administering $0.1 \mathrm{ml}$ of diluted vaccines through the oral route to each chick in their corresponding experimental groups while the same volume of PBS was administered orally to the unvaccinated control group E. Subsequently the antibody profile in vaccinated and control chicks was monitored and recorded.

\subsection{Statistical Analysis}

The differences between variables were determined by $X^{2}$ or t-test as appropriate and the level of statistical significance was established at $p \leq 0.05$. The geometric mean titres (GMT) of antibodies were calculated using the formula described in "descriptive statistics" [29]. The GMT was calculated using the formula:

$$
X_{\text {geo }}=\text { anti } \cdot \log _{10}\left(1 / n \sum f_{i} \log _{10} X_{i}\right)
$$

where $f_{i}=$ frequency and $X_{i}=$ reciprocal of dilution. The GMT is the appropriate estimate of central density in dilution assay since each individual observation is represented.

\section{Results}

Table 1 shows the pattern of hatchability of vaccinated and control eggs on different days of incubations. Significant difference $(P<0.05)$ in hatchability was observed on different days of incubation and between the different experimental groups. Highest hatchability (28 eggs) was observed on day 21 of incubation. Among the vaccinated groups, highest hatchability was observed in eggs in group A (vaccinated with ND-I ${ }_{2}$ on day 18 of incubation). In order to determine the proportion of hatched eggs in the different experimental groups, the percentage hatchability was evaluated from the total number of eggs hatched per group. The difference in percentage hatchability between the different groups was statistically significant. Highest hatchability (64\%) was recorded in group A (Table 1). Generally, the pattern of embryonic/ chick mortality was inversely proportional to hatchability. Table 2 shows the mortality pattern at hatching and post hatching among vaccinated and control embryonated eggs. Significant differences in mortality rate were observed between the different experimental groups and between the different developmental stages of the embryo. The lowest mortality rate (36\%) was recorded in group A when compared to group D (95\%), group C (90\%) and group B (64\%). Significant embryonic mortality occurred as "dead-in-shell” when compared to mortalities observed at peeping and post-hatching. Before the commencement of the experiments, 10 of the experimental eggs were randomly selected out of 124 eggs and tested for presence of ND-HI antibody to determine the baseline antibody (maternal antibody) titre. Out of the 10 eggs, 7 had detectable HI antibody and titres ranged from 1:2 to 1:4 with GMT value of $2.3 \pm 0.07$ (Table $3)$. However, the GMT value of the maternal antibody $(2.3 \pm 0.07)$ was not protective. Following in-ovo vaccination of eggs with ND-LaSota and ND- $\mathrm{I}_{2}$ vaccines on days 13 and $18 \mathrm{PH}$ respectively, the vaccinated groups $\mathrm{A}$, $\mathrm{B}, \mathrm{C}$ and $\mathrm{D}$ and unvaccinated control group $\mathrm{E}$ as well as the day-old intraocularly vaccinated group $\mathrm{F}$ were monitored for a period of 49 days PH for development of ND virus HI antibody. Monitoring of the antibody profile among vaccinated and control egg embryos revealed a considerable seroconversion (characterized by significant rise in antibody titre) among in-ovo vaccinated groups (A, B and C) when compared with the unvaccinated control group (E) which seroconverted to low and unprotective antibody titre. The day-old vaccinated intraocularly (group F) also showed evidence of seroconversion (Table 4). Significant differences $(P<0.05)$ in GMT values were observed within groups $\left({ }^{\mathrm{a}, \mathrm{b}, \mathrm{c}, \mathrm{d}}\right.$ indicating that values with different superscripts differ significantly within the group) and between groups ( ${ }^{\mathrm{g} h \mathrm{~h}}$ indicating that values with different superscripts differ significantly between groups) (Table 4 and Table 5). In addition, the pre-existing maternally derived antibody in chicks in group E waned rapidly beginning from day 21 after hatching when compared with chicks hatched from in-ovo vaccinated groups $\mathrm{A}, \mathrm{B}$ and $\mathrm{C}$ whose protective antibody titre was sustained till day $21 \mathrm{PH}$ in groups $\mathrm{A}$ and $\mathrm{B}$ and day 35 PH in group C (Table 4). Groups A and B vaccinated on day 18 of egg incubation had their peak ND virus antibody GMT values (7.30 \pm 2.08 and $6.60 \pm 2.59$ respectively) on day 7 post-hatching $(\mathrm{PH})$ which gradually and significantly declined to nonprotective levels ( $2.64 \pm 2.40$ and $2.83 \pm 2.41)$ on days 28 and 35 PH respectively. Group C had its peak ND virus antibody GMT value $(5.7 \pm 0.00)$ on day 21 PH which was sustained at protec- 
Table 1. Pattern of hatchability among vaccinated and unvaccinated control embryonated eggs on different days of incubation.

\begin{tabular}{|c|c|c|c|c|c|c|c|}
\hline \multirow{2}{*}{ Group } & \multicolumn{5}{|c|}{ Number of Chicks Hatched Daily (Day of Egg Incubation) } & \multirow{2}{*}{$\begin{array}{c}\text { Total } \\
\text { Hatched }\end{array}$} & \multirow{2}{*}{$\begin{array}{c}\% \\
\text { Hatchability }\end{array}$} \\
\hline & (20) & (21) & (22) & (23) & (24) & & \\
\hline A (vaccinated with $\mathrm{ND}-\mathrm{I}_{2}$ on day $\left.18^{*}\right) \mathrm{n}=25$ & & 7 & 6 & 3 & & 16 & 64 \\
\hline B (vaccinated with ND-LaSota on day $18^{*}$ ) n = 25 & & 4 & 3 & 1 & 1 & 9 & 36 \\
\hline C (vaccinated with ND- $\mathrm{I}_{2}$ on day $\left.13^{*}\right) \mathrm{n}=20$ & & 2 & & & & 2 & 10 \\
\hline D (vaccinated with ND-LaSota on day $13^{*}$ ) n = 20 & & 1 & & & & 1 & 5 \\
\hline E (Unvaccinated control) $n=24$ & 01 & 14 & 3 & 2 & & 20 & 83 \\
\hline Total & 01 & 28 & 12 & 6 & 1 & 48 & \\
\hline
\end{tabular}

*Day of egg incubation.

Table 2. Mortality pattern at hatching and post hatching among vaccinated and control embryonated eggs.

\begin{tabular}{|c|c|c|c|c|}
\hline \multirow{2}{*}{ Group } & \multicolumn{3}{|c|}{ Number Dead at Different Stages of Hatching and Post Hatching } & \multirow{2}{*}{$\begin{array}{l}\text { Total Number } \\
\text { (\%) Mortality }\end{array}$} \\
\hline & At Peeping & No Peeping at All (Dead-in-Shell) & Post Hatching & \\
\hline A (vaccinated with $\mathrm{ND}-\mathrm{I}_{2}$ on day $\left.18^{*}\right) \mathrm{n}=25$ & 3 & 5 & 1 & $9(36)$ \\
\hline $\mathbf{B}$ (vaccinated with ND-LaSota on day $18^{*}$ ) $n=25$ & 6 & 7 & 3 & $16(64)$ \\
\hline C (vaccinated with $\mathrm{ND}-\mathrm{I}_{2}$ on day $\left.13^{*}\right) \mathrm{n}=20$ & 5 & 13 & 0 & $18(90)$ \\
\hline D (vaccinated with ND-LaSota on day $\left.13^{*}\right) \mathrm{n}=20$ & 3 & 15 & 1 & $19(95)$ \\
\hline E (Unvaccinated control) $\mathrm{n}=24$ & 2 & 2 & 0 & $4(17)$ \\
\hline Total & 19 & 42 & 5 & \\
\hline
\end{tabular}

Table 3. Baseline ND virus HI antibody titre (maternal antibody) before egg incubation and vaccination.

\begin{tabular}{cc}
\hline Egg Number & HI Antibody Titre \\
1 & $2^{1}(1: 2)$ \\
2 & - \\
3 & $2^{2}(1: 4)$ \\
4 & $2^{2}(1: 4)$ \\
5 & $2^{2}(1: 4)$ \\
6 & $2^{2}(1: 4)$ \\
7 & $2^{1}(1: 2)$ \\
8 & - \\
9 & - \\
10 & $2^{2}(1: 4)$ \\
GMT & $2.3 \pm 0.07$ \\
\hline
\end{tabular}

tive level $(4.0 \pm 2.67)$ till day 35 PH. Only one chick hatched in group D and died the same day after exhibiting clinical signs of ND. The unvaccinated control (group E) had its nonprotective ND maternal antibody (GMT value $3.00 \pm 2.75)$ on day $7 \mathrm{PH}$ which significantly declined $(2.70 \pm 2.23)$ on day $21 \mathrm{PH}$. The day old intraocularly vaccinated group $\mathrm{F}$ had its non-protective antibody peaked $(3.82 \pm 2.33)$ on day $7 \mathrm{PH}$ and rapidly declined beginning from day $14 \mathrm{PH}$ (Table 4). Generally the pre-existing maternal antibodies in groups $\mathrm{E}$ and $\mathrm{F}$ were 
Table 4. Profile of geometric mean titre (GMT) of reciprocal of ND virus HI antibody titre in chicks hatched from ND vaccinated embryonated eggs (Groups A-E) and chicks vaccinated intraocularly at day old (Group F).

\begin{tabular}{|c|c|c|c|c|c|c|c|}
\hline \multirow{2}{*}{ Group } & \multicolumn{7}{|c|}{ GMT \pm SD of Reciprocal of NDV-HI Antibody Titre (Days Post-Hatching) } \\
\hline & (7) & (14) & (21) & (28) & (35) & $(42)^{* *}$ & $(49)^{* *}$ \\
\hline $\begin{array}{l}\text { A (vaccinated with } \\
\left.\text { ND-I } \mathrm{I}_{2} \text { on day } 18^{*}\right)\end{array}$ & $\begin{array}{c}7.30 \pm 2.08^{\mathrm{ag}} \\
\mathrm{n}=15\end{array}$ & $\begin{aligned} 6.40 & \pm 1.85^{\mathrm{ag}} \\
\mathrm{n} & =12\end{aligned}$ & $\begin{array}{c}5.30 \pm 1.95^{\mathrm{ag}} \\
\mathrm{n}=10\end{array}$ & $\begin{aligned} 2.64 & \pm 2.40^{\mathrm{bg}} \\
\mathrm{n} & =10\end{aligned}$ & $\begin{aligned} 2.83 & \pm 2.41^{\mathrm{bg}} \\
\mathrm{n} & =10\end{aligned}$ & $\begin{array}{c}11.31 \pm 3.88^{\mathrm{cg}} \\
\mathrm{n}=10\end{array}$ & $\begin{array}{c}22.64 \pm 2.11^{d g} \\
n=10\end{array}$ \\
\hline $\begin{array}{c}\text { B (vaccinated with } \\
\text { ND-LaSota on day 18*) }\end{array}$ & $\begin{array}{c}6.60 \pm 2.59^{\mathrm{ag}} \\
\mathrm{n}=7\end{array}$ & $\begin{array}{l}6.56 \pm 1.36^{\mathrm{ag}} \\
\mathrm{n}=5\end{array}$ & $\begin{array}{c}6.06 \pm 1.86^{\mathrm{ag}} \\
\mathrm{n}=5\end{array}$ & $\begin{array}{l}3.03 \pm 2.20^{\mathrm{bg}} \\
\mathrm{n}=5\end{array}$ & $\begin{array}{c}3.03 \pm 2.86^{\mathrm{bg}} \\
\mathrm{n}=5\end{array}$ & $\begin{aligned} 10.55 & \pm 1.46^{\mathrm{cg}} \\
\mathrm{n} & =5\end{aligned}$ & $\begin{aligned} 12.12 & \pm 2.20^{\mathrm{ch}} \\
\mathrm{n} & =5\end{aligned}$ \\
\hline $\begin{array}{l}\text { C (vaccinated with } \\
\text { ND-I } I_{2} \text { on day } 13^{*} \text { ) }\end{array}$ & $\begin{array}{c}5.00 \pm 2.67^{\mathrm{ag}} \\
\mathrm{n}=2\end{array}$ & $\begin{array}{c}5.40 \pm 1.63^{\mathrm{ag}} \\
\mathrm{n}=2\end{array}$ & $\begin{array}{c}5.70 \pm 0.00^{\mathrm{ag}} \\
\mathrm{n}=2\end{array}$ & $\begin{array}{c}4.00 \pm 2.67^{\mathrm{ag}} \\
\mathrm{n}=2\end{array}$ & $\begin{array}{c}4.00 \pm 0.00^{\mathrm{ag}} \\
\mathrm{n}=2\end{array}$ & $\begin{array}{c}11.34 \pm 1.63^{\mathrm{cg}} \\
\mathrm{n}=2\end{array}$ & $\begin{aligned} 16.00 & \pm 2.67^{\mathrm{ch}} \\
\mathrm{n} & =2\end{aligned}$ \\
\hline $\begin{array}{l}\text { D (vaccinated with } \\
\text { ND-LaSota on day } 13^{*} \text { ) }\end{array}$ & - & - & - & - & - & - & - \\
\hline E (Unvaccinated control) & $\begin{aligned} 3.00 & \pm 2.75^{\text {ah }} \\
n & =16\end{aligned}$ & $\begin{aligned} 3.12 & \pm 2.42^{\text {ah }} \\
\mathrm{n} & =14\end{aligned}$ & $\begin{aligned} 2.70 & \pm 2.23^{\text {ah }} \\
\mathrm{n} & =14\end{aligned}$ & $\begin{array}{c}1.49 \pm 1.42^{\mathrm{ag}} \\
\mathrm{n}=14\end{array}$ & $\begin{aligned} 1.22 & \pm 1.53^{\text {ah }} \\
\mathrm{n} & =14\end{aligned}$ & $\begin{array}{c}8.00 \pm 3.10^{\mathrm{bg}} \\
\mathrm{n}=7\end{array}$ & $\begin{aligned} 13.12 & \pm 2.88^{\mathrm{ch}} \\
\mathrm{n} & =7\end{aligned}$ \\
\hline $\begin{array}{c}\text { F (I/O hatchery } \\
\text { vaccinated chicks) }\end{array}$ & $\begin{aligned} 3.82 & \pm 2.33^{\text {ah }} \\
n & =15\end{aligned}$ & $\begin{aligned} 2.09 & \pm 1.85^{\text {ah }} \\
n & =15\end{aligned}$ & $\begin{aligned} 1.32 & \pm 1.55^{\text {bh }} \\
\mathrm{n} & =15\end{aligned}$ & $\begin{aligned} 1.12 & \pm 1.33^{\mathrm{bg}} \\
\mathrm{n} & =15\end{aligned}$ & $\begin{aligned} 0.00 & \pm 0.00^{\mathrm{h}} \\
\mathrm{n} & =12\end{aligned}$ & $\begin{aligned} 7.00 & \pm 3.37^{\mathrm{ch}} \\
\mathrm{n} & =10\end{aligned}$ & $\begin{aligned} 9.84 & \pm 3.85^{\mathrm{ch}} \\
\mathrm{n} & =10\end{aligned}$ \\
\hline
\end{tabular}

"Day of egg incubation; ${ }^{* *}$ All chicks booster-vaccinated on day 37 post hatching; ${ }^{\text {a,b,c,d }}$ Values with different superscript differ significantly $(P<0.05)$ within the group; ${ }^{\mathrm{g}, \mathrm{h}}$ Values with different superscripts differ significantly $(P<0.05)$ between the groups.

Table 5. Comparison of geometric mean titre (GMT) value of reciprocal of NDV-HI antibody in serum (S) and filter paper (FP) eluent from chicks post-hatching.

\begin{tabular}{|c|c|c|c|c|c|c|c|c|}
\hline \multirow{3}{*}{ Group } & \multicolumn{8}{|c|}{ GMT \pm SD of Reciprocal of NDV-HI Antibody Titre (Days Post-Hatching) } \\
\hline & \multicolumn{2}{|c|}{ (28) } & \multicolumn{2}{|c|}{ (35) } & \multicolumn{2}{|c|}{$(42)^{* *}$} & \multicolumn{2}{|c|}{$(49)^{* *}$} \\
\hline & S & $\mathbf{F P}$ & S & FP & S & FP & S & $\mathbf{F P}$ \\
\hline $\begin{array}{l}\text { A (vaccinated with } \\
\mathrm{ND}^{-\mathrm{I}_{2}} \text { on day } 18^{*} \text { ) }\end{array}$ & $\begin{array}{c}4.29 \pm 2.44^{\mathrm{a}} \\
\mathrm{n}=10\end{array}$ & $\begin{array}{l}2.64 \pm 2.11^{\mathrm{a}} \\
\mathrm{n}=10\end{array}$ & $\begin{array}{c}3.73 \pm 2.73^{\mathrm{a}} \\
\mathrm{n}=10\end{array}$ & $\begin{array}{c}2.30 \pm 1.89 \\
\mathrm{n}=10\end{array}$ & $\begin{array}{c}13.92 \pm 3.67^{b} \\
\mathrm{n}=10\end{array}$ & $\begin{array}{c}10.56 \pm 2.70 \\
n=10\end{array}$ & $\begin{array}{c}26.00 \pm 3.11^{b} \\
n=10\end{array}$ & $\begin{array}{l}21.11 \pm 2.40^{\mathrm{b}} \\
\mathrm{n}=10\end{array}$ \\
\hline $\begin{array}{c}\text { B (vaccinated with } \\
\text { ND-LaSota on day } 18^{*} \text { ) }\end{array}$ & $\begin{array}{l}3.03 \pm 2.86^{\mathrm{a}} \\
\mathrm{n}=5\end{array}$ & $\begin{array}{l}2.30 \pm 1.70^{\mathrm{a}} \\
\mathrm{n}=5\end{array}$ & $\begin{array}{l}2.64 \pm 3.20 \\
n=5\end{array}$ & $\begin{array}{c}2.30 \pm 2.45^{\mathrm{a}} \\
\mathrm{n}=5\end{array}$ & $\begin{array}{c}13.93 \pm 1.79^{b} \\
n=5\end{array}$ & $\begin{array}{c}10.56 \pm 1.86^{b} \\
n=5\end{array}$ & $\begin{array}{c}16.00 \pm 2.34^{b} \\
n=5\end{array}$ & $\begin{array}{c}10.55 \pm 2.20^{b} \\
\mathrm{n}=5\end{array}$ \\
\hline $\begin{array}{l}\text { C (vaccinated with } \\
\text { ND-I } I_{2} \text { on day } 13^{*} \text { ) }\end{array}$ & $\begin{array}{c}8.00 \pm 0.00 \\
\mathrm{n}=2\end{array}$ & $\begin{aligned} 5.66 & \pm 1.63 \\
\mathrm{n} & =2\end{aligned}$ & $\begin{array}{c}8.00 \pm 2.67 \\
\mathrm{n}=2\end{array}$ & $\begin{aligned} 5.66 & \pm 1.63 \\
\mathrm{n} & =2\end{aligned}$ & $\begin{array}{c}16.00 \pm 2.67 \\
\mathrm{n}=2\end{array}$ & $\begin{array}{c}11.34 \pm 1.63 \\
n=2\end{array}$ & $\begin{array}{c}22.62 \pm 4.35 \\
n=2\end{array}$ & $\begin{array}{c}16.00 \pm 2.67 \\
\mathrm{n}=2\end{array}$ \\
\hline $\begin{array}{l}\text { D (vaccinated with } \\
\text { ND-LaSota on day } 13^{*} \text { ) }\end{array}$ & - & - & - & - & - & - & - & - \\
\hline E (unvaccinated control) & $\begin{array}{c}2.56 \pm 2.22^{\mathrm{a}} \\
\mathrm{n}=14\end{array}$ & $\begin{array}{c}1.56 \pm 1.79 \\
\mathrm{n}=14\end{array}$ & $\begin{array}{l}2.21 \pm 1.71^{\mathrm{a}} \\
\mathrm{n}=14\end{array}$ & $\begin{array}{c}1.28 \pm 1.41^{\mathrm{a}} \\
\mathrm{n}=14\end{array}$ & $\begin{aligned} 11.89 & \pm 2.20^{\mathrm{b}} \\
\mathrm{n} & =7\end{aligned}$ & $\begin{array}{c}8.00 \pm 2.0 \\
n=7\end{array}$ & $\begin{array}{c}16.00 \pm 2.23^{\mathrm{b}} \\
\mathrm{n}=7\end{array}$ & $\begin{array}{c}11.89 \pm 1.97^{b} \\
\mathrm{n}=7\end{array}$ \\
\hline $\begin{array}{c}\text { F }(\mathrm{I} / \mathrm{O} \text { hatchery } \\
\text { vaccinated chicks) }\end{array}$ & $\begin{array}{c}2.30 \pm 2.12^{\mathrm{a}} \\
\mathrm{n}=15\end{array}$ & $\begin{array}{c}1.15 \pm 1.33 \\
\mathrm{n}=15\end{array}$ & $\begin{array}{l}1.89 \pm 1.79 \\
\mathrm{n}=12\end{array}$ & $\begin{aligned} 0.00 & \pm 0.00^{\mathrm{b}} \\
\mathrm{n} & =12\end{aligned}$ & $\begin{array}{c}9.20 \pm 2.20^{\mathrm{c}} \\
\mathrm{n}=10\end{array}$ & $\begin{aligned} 6.50 & \pm 3.37^{c} \\
\mathrm{n} & =10\end{aligned}$ & $\begin{array}{c}13.00 \pm 2.38^{\mathrm{c}} \\
\mathrm{n}=10\end{array}$ & $\begin{array}{c}8.57 \pm 1.48^{\mathrm{c}} \\
\mathrm{n}=10\end{array}$ \\
\hline
\end{tabular}

"Day of egg incubation; ${ }^{* *}$ All chicks booster-vaccinated on Day 37 post hatching; ${ }^{\text {a,b,c,d }}$ Values with different superscript differ significantly $(P<0.05)$ within the group; ${ }^{\text {g,h }}$ Values with different superscripts differ significantly $(P<0.05)$ between the groups.

nonprotective and decayed rapidly when compared with the in-ovo vaccinated groups A, B and C whose antibodies were protective and sustained longer. On day $42 \mathrm{PH}$ (day 7 post booster-vaccination [PBV]), there was significant rise in GMT values in all the groups possibly through anamnestic immune response. During the period of the experiments, between day 7 and $21 \mathrm{PH}$, blood samples were collected from experimental chicks on filter papers alone. From day 28 to $49 \mathrm{PH}$, blood samples were collected on both filter papers alongside whole blood for serum for comparative analysis. Simultaneous analyses of both serum samples and filter paper eluents for presence of ND antibody revealed a 2 - 3 fold difference between serum and filter paper eluents in some groups 
as shown in (Table 5). Higher antibody titres were consistently recorded in serum samples when compared with filter paper eluents. On day $49 \mathrm{PH}$ the chicks in group $\mathrm{C}$ showed the highest antibody titre difference between the two samples (22.63 \pm 4.35 for serum and $16.0 \pm 2.67$ for filter paper).

\section{Discussion}

ND continues to pose serious public health and economic challenges to both small holder and commercial poultry worldwide. Vaccination is the only remedy for this scourge but the success of vaccination depends on the effectiveness and dependability of the method of vaccination.

In this study, we determined the usefulness of in-ovo vaccination in the control of ND and compared the decay of in-ovo vaccinal antibody in groups A, B, C and D with the duration of decay of maternal antibody in unvaccinated control chicks in group $E$ and decay of vaccinal antibody in intraocularly vaccinated chicks in group F. In addition, the study also compared the safety and efficacy of the existing live ND vaccines (LaSota and $\mathrm{I}_{2}$ ) for chick embryos when used in in-ovo vaccination. This study has demonstrated the use of ND-LaSota and ND- $\mathrm{I}_{2}$ vaccines for in-ovo vaccination of embryonated chicken eggs for protection of chickens against ND. In-ovo vaccination of 13-day-old embryonated eggs resulted in higher embryonic mortality when compared with the mortality observed with vaccinated 18-day-old embryonated eggs. Significant number of embryos survived and had higher hatchability when the two ND vaccines (LaSota and $\mathrm{I}_{2}$ ) were administered to 18-day-old through the in in-ovo vaccination. In addition, significant differences in embryonic survival and hatchability were observed between embryos vaccinated with $\mathrm{ND}-\mathrm{I}_{2}$ or ND-LaSota. Higher embryo survival and hatchability were noted with ND-I .

Previous studies have consistently demonstrated that several live vaccines cannot be administered in-ovo, mainly because vaccine virus causes considerable embryonic mortality [24] [25], reduced hatchability [22], or development of clinical disease after hatch [21]. Selection of highly attenuated virus strain, virus modification, and inoculum dose that exert least harmful effects on embryos or neonatal chicks are critical in the development of a live vaccine for in-ovo application [26]. This study has revealed that the two live ND vaccines (LaSota and $\mathrm{I}_{2}$ ) used in the in-ovo vaccination were pathogenic for 13-day-old and 18-day-old embryonated eggs (Table 1). Significant percentage of the embryonic death occurred in the shell (dead-in-shell) indicating higher pathogenicity of the ND vaccines for the embryo (Table 2). There was significant reduction in hatchability and considerable embryonic mortality among the vaccinated eggs (groups B, C and D) when compared with unvaccinated control (group E). However, the difference in the two conditions between vaccinated eggs in group A and unvaccinated control group E was not significant. Eighteen-day-old embryos in group A (vaccinated with ND-I I $_{2}$ tolerated the vaccine more than any of the vaccinated groups. The relatively lower embryonic death recorded in group A could be due to low pathogenicity of $\mathrm{ND}-\mathrm{I}_{2}$ which is a naturally occurring avirulent strain of ND virus.

A low level of maternal antibody to ND virus (GMT $2.3 \pm 0.07$ ) was detected in embryonated eggs before the in-ovo vaccination. This level of maternally derived antibody may not be protective against ND virus infection and could be partly responsible for absence of maternal antibody interference with ND vaccine used in the in-ovo vaccination. The embryos in groups A, B and C seroconverted to protective ND virus antibody titres following in-ovo vaccination and the developed antibody was sustained for a longer period in chicks after hatching when compared with control group $\mathrm{E}$ and intraocularly vaccinated group $\mathrm{F}$ whose antibodies were not protective and decayed faster. This observation has demonstrated the potential application of in-ovo method for vaccination of chick embryos for protection against ND. However, the vaccines used in this study were pathogenic for the chick embryos and further studies will be required in order to identify vaccine candidates for in-ovo vaccination against ND in this environment. For instance, in this study, the naturally occurring ND- $\mathrm{I}_{2}$ vaccines was found to be relatively less pathogenic than ND-LaSota and further studies on the former (including dose, maternal antibody interference, age and site of embryo inoculation) need to be pursued in a more carefully designed experiment. Booster vaccination of experimental chicks on day $37 \mathrm{PH}$ resulted in significant rise in antibody titre in all the vaccinated birds possibly due to anamnestic response.

In-ovo vaccination has several advantages over the conventional methods of vaccination, like neonatal resistance (avoidance of vaccine and maternal antibody interference), administration of uniform dose of virus and better protection, administration of vaccine in eggs en masse, reduces labour cost and farmer's involvement [20] [21]. This study has demonstrated the potential use of live ND vaccines (LaSota and $\mathrm{I}_{2}$ ) for in-ovo vaccination of chicken embryo for protection of chickens against the disease. The in-ovo vaccinated embryos seroconverted to protective antibody titre and they remained protected against ND after hatching. However, the ND vaccines used 
in this study may not be suitable for in-ovo application considering the marked embryo mortality and the resulting poor hatchability. The maternally derived antibody in chick embryos in unvaccinated control group E was not protective and decayed faster in chicks after hatching. The pre-existing maternal antibody in chick embryos did not interfere with ND vaccines following in-ovo vaccination. The in-ovo vaccinated embryos seroconverted to protective antibody titre in spite of the pre-existing antibody. In-ovo vaccination conferred a better protective antibody to ND virus when compared with the conventional day old intraocular vaccination method. The antibody developed following intraocular vaccination decayed earlier than that of in-ovo vaccination.

A practical method for collection and processing of dried whole blood samples on filter paper was developed to facilitate large scale testing programmes for ND virus and Avian influenza virus antibodies [30] as well as Avian infections bronchitis virus antibody [31]. In this study, a 2 - 3 fold difference in ND antibody titre was noted between the filter paper eluent and serum. Serum antibody titre was consistently higher than the level of antibody detected in the filter paper eluent. However, the difference between them was not statistically and practically significant. Besides, the storage of filter paper at $+4^{\circ} \mathrm{C}$ has not affected the ND antibody level in the filter paper eluent. The finding was in agreement with previous reports on the difference in antibody titre between serum and filter paper eluents, [30] [31]. However in this experiment there was a higher fold difference in antibody titre greater than what was previously reported. The use of a modified paper punch to cut and place dried blood sample simultaneously into a standard 96 well microtitre plate for elution of antibody has been reported [30]-[32]. Dried blood titres were not markedly affected by method of drying, storage or storage at $4^{\circ} \mathrm{C}$ for 8 days or $30^{\circ} \mathrm{C}$ for 14 days [30]. Roy et al. [32] however reported that there is reduction of antibody titre after 21 days of storage of sample of dried blood at room temperature. Blood dried on filter paper is a satisfactory sample for assay of $\mathrm{HI}$ antibodies to ND virus and AI [32].

Based on the results of this study, there is the need for the selection of a highly attenuated ND vaccine strain for the in-ovo vaccination of broilers and determine the inoculum dose that exerts the least harmful effects on embryos or neonatal chicks. The possibility of pre-existing maternal antibody interference with vaccine used in in-ovo vaccination requires further investigation. These factors are critical in the development of live vaccine for in-ovo application in Nigeria.

\section{Acknowledgements}

The authors thankfully acknowledge the technical assistance of Andrew Ali and Awa Nabi. The senior author was a postgraduate (MSc Microbiology) student in the Department.

\section{References}

[1] Alexander, D.J. (1997) Newcastle Disease and Other Paramyxovirus Infections. In: Calnek, B.W., Barnes, H.J., McDougall, L.R., Saif, Y.M. and Beard, G.W., Eds., Diseases of Poultry, Iowa State University Press, Ames, 541-569.

[2] Calnek, B.W., Barnes, H.J., Beard, C.W., Reid, W.M. and Yoder, H.W. (1991) Diseases of Poultry. Iowa State University Press, Ames, 496-513.

[3] Baba, S.S., Undiandeye, U.J. and Abubakar, M.B. (2004) Species Difference in Immune Responses of Village Poultry to Newcastle Disease and Infectious Bursal Disease Vaccines. Vom Journal of Veterinary Science, 1, 68-77.

[4] Alders, R. and Spradbrow, P.B. (2001) Controlling Newcastle Disease in Village Chickens. Australian Centre for International Agricultural Research (ACIAR): Monograph No. 82, Canberra, 9-14.

[5] Baba, S.S. and El-Yuguda, A.D. (1999) Newcastle Disease Virus in Nigeria: Evidence of Antigenic Diversity among Field Isolates and Vaccine Strains. Journal of Life and Environmental Sciences, 1, 15-17.

[6] El-Yuguda, A.D. and Baba, S.S. (2002) Prevalence of Selected Viral Infections in Various Age Groups of Village Chickens in Borno State Nigeria. Nigerian Journal of Animal Production, 29, 245-250.

[7] Alexander, D.J. (1989) Newcastle Disease. In: Laboratory Manual for the Isolation and Identification of Avian Pathogens, 3rd Edition, Kendal/Hunt Publishing Company, Dubuque, 114-120.

[8] Beard, C.W. and Hanson, R.P. (1981) Newcastle Disease. In: Hofstad, M.S., Ed., Diseases of Poultry, 7th Edition, Iowa State University Press, Ames, 452-470.

[9] Brown, C., King, D.J. and Seal, B.S. (1999) Pathogenesis of Newcastle Disease in Chickens Experimentally Infected with Viruses of Different Virulence. Veterinary Pathology, 36, 125-136. http://dx.doi.org/10.1354/vp.36-2-125

[10] Lancaster, J.E. and Alexander, D.J. (1975) Newcastle Disease Virus and Spread. Canada Department of Agriculture, 
Monograph No. 11, Ottawa.

[11] Kouwenhoven, B. (1993) Newcastle Disease. In: Knudsen, R.C., Slazyk, W.E. and Richmond, J.Y., Eds., Virus Infection of Domestic Birds, Elsevier Science Publishers, Amsterdam, 341-361.

[12] Awong, I.D.R., Wan, W.S., Ahmed, K. and Abdulrazak, J. (1992) Detection of Maternal Antibody against Newcastle Disease Virus in Chicks Using an Indirect Immunoperoxidase Test. Malaysian Journal of Veterinary Medicine, 4, 19-32.

[13] El-Yuguda, A.D. and Baba, S.S. (2007) Antibody Response of Village Chickens to Single or Combined Viral Vaccines: Effect of Maternal Antibodies and Vaccine Interactions. Proceedings of the 12th International Conference of the Association of Institutions for Tropical Veterinary Medicine, Montpellier, 19-22 August 2007, 215-220.

[14] Allan, W.H., Lancaster, J.E. and Toth, B. (1978) Newcastle Disease Vaccine: Their Production and Use. FAO/UNO, Rome, 57-62.

[15] Rahman, M.M., Bari, A.S.M., Giasudin, M.J., Islam, R.M. and Sil, A.C. (2002) Evaluation of Maternal and Humoral Immunity against Newcastle Disease Virus in Chicken. International. Journal of Poultry Science, 1, 161-163. http://dx.doi.org/10.3923/ijps.2002.161.163

[16] Saeed, Z., Ahmad, S., Rizvi, A.R. and Ajmal, M. (1988) Role of Maternal Antibody in Determination of an Effective Newcastle Disease Vaccination Programme. Pakistan Journal of Veterinary Research, 1, 18-20.

[17] Eissa, Y.M. (1985) Disease Control Problems in the Middle East. World Poultry, 33-37.

[18] Giambrone, J.J. and Closser, J. (1990) Effects of Breeder Vaccination on Immunization of Progeny against Newcastle Disease. Avian Diseases, 34, 114-119. http://dx.doi.org/10.2307/1591341

[19] El-Yuguda, A.D. and Baba, S.S. (2004) An Outbreak of Infectious Bursal Disease in Eight Weeks Old IBD Vaccinated Commercial Poultry Flock in Maiduguri, Nigeria. Tropical Veterinarian, 22, 93-98.

[20] Sharma, J.M. and Burmester, B.R. (1982) Resistance to Marek's Disease at Hatching in Chicken Vaccinated as Embryos with the Turkey's Herpesvirus. Avian Diseases, 26, 134-149. http://dx.doi.org/10.2307/1590032

[21] Sharma, J.M. (1985) Embryo Vaccination with Infectious Bursal Disease Alone or in Combination with Marek’s Disease Vaccine. Avian Diseases, 29, 1155-1169. http://dx.doi.org/10.2307/1590469

[22] Sharma, G., Greer, W., Gildersleeve, R.P., Murray, D.L. and Miles, A.M. (1995) Field Safety and Efficacy of in Ovo Administration of HVT+SB-1 Bivalent Marek’s Disease Vaccine in Commercial Broilers. Avian Diseases, 39, $211-217$. http://dx.doi.org/10.2307/1591862

[23] Riaz, M.N., Hussain, I., Akhtar, M., Rasool, M.H., Mansoor, N.K. and Haq, S.E.U. (2004) Evaluation of in Ovo Vaccination against Infectious Bursal Disease Virus in Commercial Broilers in Pakistan. International Journal of Agriculture and Biology, 6, 984-986.

[24] Wakenell, P.S. and Sharma, J.M. (1986) Chicken Embryonal Vaccination with Avian Infectious Bronchitis Virus. American Journal of Veterinary Research, 47, 933-937.

[25] Ahmad, J. and Sharma, J.M. (1992) Evaluation of a Modified-Live Virus Vaccine Administered in Ovo to Protect Chickens against Newcastle Disease Virus. American Journal of Veterinary Research, 53, 1999-2004.

[26] Chandana, M., Manna, S.K., Das, R. and Roy, R.N. (2007) Development of in Ovo Vaccine against Newcastle Disease of Birds. Current Science, 93, 1305-1309.

[27] Allan, W.H. and Gough, R.E. (1974) A Standard Haemagglutination Inhibition Test for Newcastle Disease. A Comparison of Macro and Micro Methods. Veterinary Record, 95, 120-123. http://dx.doi.org/10.1136/vr.95.6.120

[28] Pela, T.H., Gulka, C.M., Yates, V.J. and Chang, P.W. (1984) Use of Egg Yolk in Serological Test (ELISA and HI) to Detect Antibody to Newcastle Disease, Infectious Bronchitis and Mycoplasma gallisepticum. Avian Diseases, 28, 877-883. http://dx.doi.org/10.2307/1590264

[29] CDC (Centre for Disease Control) (1988) Descriptive Statistics: Measure of Central Tendency and Dispersion. Centre for Disease Control and Prevention Atlanta, Georgia.

[30] Burgh, M. and Beard, C.W. (1980) Collection and Processing of Blood Samples Dried on Paper for Microassay of Newcastle Disease Virus and Avian Influenza Virus Antibody. American Journal of Veterinary Research, 41, 14951498.

[31] Ambali, A.G. and Jones, R.C. (1991) Efficiency of Filter Paper for Measurement of Antibody to Avian Infectious Bronchitis. Bulletin of Animal Health \& Production Africa, 39, 213-218.

[32] Roy, P., Nachimuthu, K. and Venugopalan, A.T. (1992) A Modified Filter Paper Technique for Serosurveillance of Newcastle Disease. Veterinary Research Communications, 16, 403-406. http://dx.doi.org/10.1007/BF01839189 